\title{
Assessment of Floristic Composition of Kilim Geoforest Park, Langkawi, Malaysia
}

\author{
G. Fatheen Nabila, I. Faridah-Hanum (Corresponding author), Kamziah Abd Kudus \& M.Nazre \\ Faculty of Forestry, University Putra Malaysia, 43400 Serdang, Selangor, Malaysia \\ Tel: 60-3-8946-7171 E-mail: i.faridahhanum@gmail.com
}

$\begin{aligned} & \text { Received: July 1, 2011 } \\ & \text { doi:10.5539/jas.v4n3p23 }\end{aligned} \quad$ URL: http://dx.doi.org/10.5539/jas.v4n3p23

The research is financed by Research University Grant Scheme, Universiti Putra Malaysia (91037)

\begin{abstract}
The present study was carried out to analyze the species diversity and quantitative analysis of mangrove forest in three riverine ecosystems at River Kisap, River Ayer Hangat and River Kilim at Kilim Geoforest Park. One hundred plots, each of size $20 \mathrm{~m} \times 20 \mathrm{~m}$, were established at a distance of $250 \mathrm{~m}$ apart along the three rivers. Every existing species that occurred within the plot and trees of diameter at breast height of $1 \mathrm{~cm}$ and above were enumerated and identified. The data were analyzed for species richness, diversity and evenness. The species richness were computed based on the Jacknife method, species diversity index were calculated using Simpson's Index, Shannon-Wiener Index and Brillouin's Index. The evenness indexes were measured by Simpson's measure of evenness, Camargo's index of evenness and Smith and Wilson's index of evenness. A total of 11488 individual trees representing 58 species, 39 genus, and 23 families were recorded. The most abundant species was Rhizophora apiculata (3449) and Ceriops tagal (2060). The diversity results show that Shannon-Wiener, Simpson's index of diversity and Brillouin index was high (2.0 to 3.0), (0.7 to 0.8$)$, to (2.0 to $3.0)$ respectively and the evenness index however was low (0.1 to 0.2$)$.
\end{abstract}

Keywords: Floristic composition, Mangrove forest, Diversity index, Kilim Geoforest Park, Langkawi

\section{Introduction}

Langkawi is an archipelago of 104 islands situated at $6^{\circ} 21^{\prime} \mathrm{N} ; 99^{\circ} 48^{\prime} \mathrm{E}$ to the north of the Straits of Malacca. The total area is about 47,848 ha. The topography of Langkawi is mainly flat to mountainous, rising up to 881 meter height, which is the highest peak at Gunung Raya. Langkawi Geoforest Park comprising all of the 99 islands and the total land area of Kilim Geoforest Park is about 478 square kilometers comprises of three main river basins i.e. River Kilim, River Ayer Hangat and River Kisap. Kilim Geoforest Park experiences dry season lasting two to three months between December and March, which may influences the flora to have an affinity to those happened in Burma and Thailand. The ecosystems of the old limestone rock formation, the caves, the mudflats and the seas that surround it have three main types of vegetation i.e. the mangroves, the vegetation of the limestone hills and the flora of the mudflats and beaches.

Mangroves are defined as plants, shrubs, palms and ferns that are growing within the inter-tidal region of coastal and estuarine environments in the tropics and subtropics. The important of mangroves in the world was given by Tomlinsons (1986). Mangrove areas in Langkawi cover approximately 3142 ha (JPSM, 2003) and the largest area is at the Kisap Forest Reserve with 1336 ha of mangrove forest. Mangroves of Langkawi are considered as unique and rare occurrence, in the sense that they are found on shallow limestone substratum areas. Japar (1994) reported that Malaysia has 38 exclusive, 57 non-exclusive and more than 10 associated mangrove biota. Thus, this data proved Malaysia as one of the diverse mangrove population in the world.

Mangrove forest promotes a unique root system with a physiology of the plant species that are capable of preventing soil erosion and cleaning water contaminated with metallic pollutants (Norhayati \& Latiff, 2001). The mangrove also serves as breeding grounds to many species of fishes, prawn and other sea life. The mangrove vegetation in this area is quite diverse and includes many important species; some with medicinal properties. The limestone hills of the area have a rich diversity of species of ornamental plants such as the cycads and orchids, the limestone rocks also support many bryophytic flora, lichens and macro fungi (Norhayati \& Latiff, 2001). Nowadays, shorelines are one of the most rapidly changing areas on the Earth. Based on literitures as many as 3 billion people inhibit within $60 \mathrm{~km}$ of a shoreline areas (Woodroffe, 2002). Because of this huge populations that inhabit in the areas near the coast to take benefit of valuable marine resources and also to participate in seaborne 
trade with other countries. Thus this activities reaping socio-economic benefits to the commutities directly and to the country indiretly. In terms of ecology aspect, the coast and its adjacent areas may form a unique ecosystem. This is due to combine influence of both fresh and saline water. Because of this interaction the coastal landforms could support a large diversity of flora and fauna, which are crucial to the food chain. Hence, this is one of the important resources that the coast offers is the mangrove ecosystem, which is amongst the world's most productive ecosystems (Mitsch \& Gosselink 1993; Odum et al. 1982).

Since the mangrove forests of Langkawi especially at Kilim Geoforest Park areas are facing impacts from increasing of boat traffic, coastal development such as reclamation, erosion, accretion and sedimentation, which are mostly for ecotourism activities. Hence, the objective of this study is to assess floristic composition and diversity of Kilim Geoforest Park. This study is necessary to begin conservation assessment that will provide baseline ecological data for sustainable management of the mangrove forest in Malaysia.

\section{Methodology}

\subsection{Description of study area}

The study area is situated between latitude of $6^{\circ} 29^{\prime} 33.20^{\prime \prime}$ to $6^{\circ} 23$ ' 6.24" North and between longitude $99^{\circ} 48^{\prime}$ 0.34 ' to $99^{\circ} 55^{\prime} 30.86^{\prime \prime}$ East at the northeast of Langkawi Island within the state of Kedah, Malaysian. The study area was divided into three study sites i.e. River Kisap, River Kilim and River Ayer Hangat of Kilim Geoforest Park. These three riverine were rich with mangrove forest, flourished on limestone formation, which is a rare occurrence. The topography varies from flat coastal plains, hilly areas to rugged mountains.

\subsection{Methods}

The field survey for the ecological study was conducted in November 2009 until February 2010. The study areas were visited three times during the study periods. In this study, a total of 100 study plots of about $20 \mathrm{~m} \times 20 \mathrm{~m}$ quadrats $(400 \mathrm{sq} \mathrm{m})$ size were established. About 40 plots were placed at the elevation $6.4 \mathrm{~m}$ a.s.1 and the intervals of $250 \mathrm{~m}$ along River Kilim and 30 study plots along River Kisap and River Ayer Hangat each. Data were gathered from each quadrate. All the trees in the plot with diameter at breast height $(\mathrm{DBH})>1 \mathrm{~cm}$ were enumerated, measured and identified. Other parameters recorded were species name and height (HT). In this study, the specimens, both mangrove and non-mangroves, were collected, placed in transparent plastic bag and labeled properly. They were then brought back to the laboratory in Faculty of Forestry of University Putra Malaysia. Samples were preserved as Herbaria and a few of them were dissected to identify the specimens. They were identified using the mangrove identification manuals and standard Floras (Ng \& Sivasothi, 1999; $\mathrm{Ng}$ 1978;1989; Whitmore, 1972;1973). The specimens whose identity could not be confirmed were sent to experts for further identification and verification. Precise GPS locations were recorded from all the field areas visited.

\subsubsection{Quantitative analysis}

Important quantitative analysis such as density, frequency and abundance of tree species and non trees species were calculated based on the method that was suggested by Curtis and McIntosh, (1950).

\section{Density}

Density is an expression of the numerical strength of a species where the total number of individuals of each species in all quadrats is divided by the total number of quadrats studied.

$$
\text { Density }=\underline{\text { Total number of individuals of a species in all quadrats }}
$$

Total number of quadrats studied

\section{Frequency (\%)}

This refers to the degree of dispersion of individual species in an area and expressed in terms of percentage occurrence.

$$
\text { Frequency }(\%)=\frac{\text { Number of quadrats in which the species occurred }}{\text { Total number of quadrats studied }} \times 100
$$

\section{Abundance}

Referring to the number of individuals of different species in the community per unit area.

$$
\text { Abundance }=\underline{\text { Total number of individuals of a species in all quadrats }}
$$

\section{Important Value Index}

This index is used to determine the overall importance of each species in the community structure. To calculate this index, the percentage values of the relative frequency, relative density and relative dominance are summed up together and designated as Important Value Index (IVI) of the species (Curtis, 1959). 


\section{Relative density $=\underline{\text { Number of individual of the species }} \quad \times 100$}

Number of individual of all the species

Relative frequency $=$ Number of occurrence of the species $\quad \times 100$

Number of occurrence of all the species

Relative dominance $=$ Total basal area of the species $\quad \times 100$

Total basal area of all the species

Data for computing species richness, evenness and diversity indices were analyzed using Ecological Methodology Software (Krebbs, 1998) formula as below:

\section{Species richness}

Jackknife estimate

$$
\widehat{\mathrm{S}}=\mathrm{s}+\left(\frac{\mathrm{n}-1}{\mathrm{n}} \mathrm{k}\right)
$$

Where:

$\hat{s^{\wedge}}=$ jackknife estimate of species richness

$s=$ total number of species present in quadrates

$\mathrm{n}=$ total number of quadrates samples

$k=$ number of unique species (species which occur in only one quadrate)

\section{Species diversity}

Simpson's Index

$$
\widehat{\mathrm{D}}=1-\sum \mathrm{Pi}^{2}
$$

Where:

^ $D=$ Simpson’s index

$P i=$ proportion of species $i$ in the community

Shannon-Weiner measure

$$
\mathrm{H}^{`}=\sum(\mathrm{Pi})(\log \mathrm{Pi})
$$

Where:

$H^{\prime}=$ information content of sample (bits/individual) and index of diversity

$s=$ number of species

$P i=$ proportion of total sample belonging to $i$ species

\section{Species evenness}

Simpson's measure of evenness

Where:

$$
\mathrm{E}_{1 / \mathrm{D}}=(1 / \widehat{\mathrm{D}}) / \mathrm{s}
$$

$E_{l / D}=$ Simpson measure of evenness

$S=$ number of species in the sample

$\widehat{\mathrm{D}}=$ Simpson index

Smith and Wilson's index of evenness

Where:

$$
\mathrm{E}_{\mathrm{var}}=1-\left[2 /\left(\pi \arctan \left\{\sum_{\mathrm{i}=1}^{\varepsilon}\left(\log _{\mathrm{e}}\left(\mathrm{n}_{\mathrm{i}}\right)-\sum_{\mathrm{j}=1}^{\varepsilon}\left(\frac{\log _{\mathrm{e}}\left(\mathrm{n}_{\mathrm{j}}\right)}{\mathrm{s}}\right)^{2} / \mathrm{s}\right)\right\}\right.\right.
$$

Evar $=$ Smith and Wilson's index of evenness

$n i=$ Number of individuals in species $i$ in sample $(i=1,2, \ldots, s)$

$n j=$ Number of individuals in species $j$ in sample $(j=1,2, \ldots, s)$ 
$s=$ Number of species in entire sample

\section{Results}

\subsection{Main Floristic Attributes and Dominance}

A total of 11488 individual were recorded from the three locations i.e. River Kisap, River Ayer Hangat and River Kilim. These trees belonged to 23 families, 39 genus and 58 species (Table I and II). Avicenniaceae, Rhizophoraceae, Moraceae, Lythraceae, Polygalaceae and Meliaceae were distributed in most study areas. However, Ebenaceae and Euphorbiaceae were appeared at least in two different locations in this study. On the other hand the rest of the family were appeared only in one location.

(Note 1)

At River Ayer Hangat, 16 species of plant was recorded and the most abundant species were Xylocarpus granatum, with 1517 of individual, and this was followed by Rhizophora apiculata (1109), Ceriops tagal (429), Rhizophora mucronata (265) and Brugueira parviflora (91). On the other hand, the highest number of plant species was recorded in River Kisap which consisting of 48 species. The total individual in this area was 3832 individuals. The abundant species recorded in River Kisap were Rhizophora apiculata (1114), Bruguiera cylindrica (1110), Ceriops tagal (367), Bruguiera parviflora (311), Xylocarpus granatum (253) and Rhizophora mucronata (244). The highest number of individuals was recorded in River Kilim consisted of 4051 of individual. In this area the abundant species were Ceriops tagal (1264), Rhizophora apiculata (1226), Brugueira sexangula (465), Rhizophora mucronata (455), Bruguiera parviflora (424) and Xylocarpus granatum (124).

\subsection{Mangrove Composition and Dominance}

For mangrove composition assessment, a total of 11148 trees were recorded in 100 study plots belonged to 4 families, 7 genera and 12 species (Table III and IV). Among the families in the plot, Rhizophoraceae was the most diverse with 3 genera and eight species respectively. This result is not surprising since this family is the largest family of mangrove trees in Malaysia. (Note 2)

Rhizophoraceae accupied $80.37 \%$ of total population which is the most diverse family in the study areas. This was followed by Avicenniaceae, Euphorbiaceae and Meliaceae; $18.58 \%, 1.01 \%$ and $0.04 \%$, respectively. Interestingly, mostly mangrove species such as Rhizophora apiculata, Rhizophora mucronata, Xylocarpus granatum and Ceriops tagal were found distributed fairly in all study areas. These species of mangrove were also identified as dominance species in the study area. On the other hand, 5 mangrove species such as Xylocarpus rumphii and Ceriops decandra were only appeared in River Ayer Hangat and River Kisap, respectively. Similar situation was observed on Avicennia officinalis, Bruguiera gymnorrhiza and Bruguiera sexangula, where they only recorded in River Kilim.

\subsection{Important Species and Species Diversity}

Data on important species of Kilim Geopark Langkawi were summarized in Table V and VI. In the study area, eight species of true and associate mangroves were identified as the most important species, they were Rhizophora apiculata, Ceriops tagal, Xylocarpus granatum, Rhizophora mucronata, Brugueira cylindrica, Brugueira parviflora, Bruguiera sexangula and Avicennia marina with their IVI values were 87.55, 45.55, 40.45, $30.28,22.60,22.12,11.29$ and 7.79 , respectively. These species were also high in terms of density per hectare and frequency.

(Note 3)

Rhizophora apiculata, Rhizophora mucronata, Ceriops tagal, Xylocarpus granatum and Brugueira parviflora were the important species of mangrove trees in River Ayer Hangat, River Kilim and River Kisap. These species of mangrove trees life abundantly in those areas make up of more than $50 \%$ of total population. On the other hand, Avicennia marina, Avicennia officinalis and Brugueira cylindrica were only important in selected areas. For instance, Avicennia marina were only appeared at River Ayer Hangat and River Kisap. Avicennia officinalis and Bruguiera cylindrica were only recorded in River Kilim and River Kisap, respectively.

In terms of family value index (FVI), Rhizophoraceae was the most important mangrove family in the Kilim Geopark with FVI value of 224.77 (Table VII). This was followed by Meliaceae and Avicenniaceae with FVI values of 46.84 and 10.66 , respectively. On the other hand, aassociate mangrove family were exhibited in a small population in the study areas.

(Note 4)

For species diversity study, three parameters were used namely species richness, heterogeneity and evenness (Table VIII). According to Jackknife index, River Kisap (62.9) was the richest area with mangrove species in the 
Kilim Geopark as compared to River Ayer Hangat (25.7) and River Kilim (24.7). River Kisap contain 15 unique mangrove species.

For species heterogeneity assessment, Simpson's index, Shannon-Wiener index and Brillouin index were used in this study. All index showed that River Kisap was the most diverse area in Kilim Geopark and followed by River Kilim and River Ayer Hangat. River Kilim has the most evenness index in the Kilim Geopark and followed by River Ayer Hangat and River Kisap.

\section{Discussion and Conclusion}

Langkawi Geoforest Park is positioned as an archipelago of 99 islands. In 2007, it was awarded the Geopark status by the United Nations Educational, Scientific and Cultural Organisation (Unesco) for its geological history dating back some 500 million over years. Hence, the findings of this study were very important in order to conserve this world heritage area, in terms of management of mangrove diversity. Based on our findings, Rhizophora apiculata and Rhizophora mucronata were two dominant species in the Kilim Geopark. Our findings are parallel with the previous study conducted by Norhayati and Latiff (2001) in the Kisap Forest Reserve. Their study revealed that Rhizophora apiculata is the most dominant species together with other nine mangrove species.

In our study, we found that the total number of individual of Rhizophora in Kilim Geopark is far greater; 1109 trees per ha were recorded in River Ayer Hangat, 1114 trees per ha in River Kisap and 1226 trees per ha at River Kilim as compared to Kisap Forest Reserve; 557 trees per ha (Norhayati and Latiff, 2001) and 819 trees per ha in Balok River, Pahang (Rozainah and Mohamad, 2006). In comparison Matang Forest Reserve however recorded the highest total number of Rhizophora trees with 2190 per ha (Gong and Ong, 1995). According to Lokman and Sulong (2001), Peninsular Malaysia has one of the most diverse mangrove assemblages in the world, with at least 38 exclusive and 57 non-exclusive and associate mangrove species. Interestingly, in our findings, Kilim Geopark, contain at least 52 mangrove species of which 14 species are true mangrove and 38 are associate mangrove species. As comparison in River Balok, Pahang, at least 16 mangrove species were recorded of which four species are associate mangrove.

Similar study in the Pondicherry State of South India by Balachandran et al. (2009) revealed that 41 species of mangrove were recorded of which 18 species are true mangrove and 23 species are associate mangrove. In their report showed that Rhizophora sp. is one of the dominant species and this is also true in our study areas. However, in Purna Estuary Gujarat, India seven species of true mangrove species were reported (Bhatt et al. 2009). They were Avicennia marina var. marina, Sonneratia apetala, Acanthus ilicifolius, Rhizophora mucronata, Ceriops tagal, Bruguiera cylindrica and Aegiceras corniculatum and most of the species were also reported in our study. This is proved that main important mangrove species were still present intact in the study areas and their existent must be protected and managed properly for our future generation.

According to Curtis and McIntosh (1951), if the IVI is more than 10, it shows that the species is dominant to that area. In our findings showed that Kilim Geoforest Park mangrove forest can be considered as Rhizophora-Ceriops zone. The diversity estimated using Shannon-Wiener, Simpson's index of diversity and Brillouin index was high and the evenness index however was low (0.1 to 0.2). The Smith and Wilson's index of evenness is more preferred compared the others because it is independent of species richness and sensitive to both and rare common species (Krebbs, 1999).

The reduction of mangrove forests have been observed in most states in the Peninsular of Malaysia (Latiff, 2004). Inspite of their immense role in protecting human resource and biodiversity, these unique mangrove forest have been facing tremendous threats such as exploitation of mangrove resources for multiple uses such as fodder, fuel wood, timber for building material, alcohol, paper, charcoal and medicine (Upadhyay et al. 2002). Apart from those, conversion of forest areas to aquaculture and agriculture sites, construction of port and harbour, extension of human inhabitation, over-grazing, urbanization, industrialization and pollution are major common occurrences that dwindle mangrove forest in the world (Blasco \& Aizpuru 1997; Naskar 2004; Upadhyay et al. 2002). In Langkawi itself, uncontroll land development extivities such as development of Langkawi cable car as well as tourism arrivals to Langkawi up to 1.88 million people every year may threaten natural environment of the study areas in the long run. Steps have been taken by Forestry Department to conserve some of mangrove forests as forest reserve area such as Kisap Forest Reserve.

\section{References}

Balachandran, N., Kichenamourthy, S., Muthukumaran, J., Jayakanthan, M., Chandrasekar, S., Punetha, A., and Sundar, D. (2009). Diversity of true mangroves and their associates in the Pondicherry region of South India and development of a mangrove knowledgebase. J. Ecol. Nat. Environ, 5: 099-105. 
Bhatt, S., Shah, D.G., \& Desai, N. (2009). The mangrove diversity of Purna Estuary, South Gujarat, India. Tropical Ecology, 50: 287-293.

Blasco, F. \& M. Aizpuru. (1997). Classification and evolution of the mangroves of India. Tropical Ecology, 38: 357-374.

Curtis, J.T. (1959). The vegetation of Wisconsin. An Ordination of Plant communities, University Wisconsin, 657.

Curtis, J.T., \& McIntosh, R.P. (1951). An upland forest continuum in the prairie-forest border region of Wisconsin. Ecology, 32: 476 - 496. http://dx.doi.org/10.2307/1931725

Forestry Department of Peninsular Malaysia (JPSM). (2003). Keluasan hutan paya bakau Kepulauan Langkawi berdasarkan hutan simpan tahun 2003. Unit Teknologi Maklumat. Ibu Pejabat Jabatan Perhutanan.

Gong, W.K. \& J.E. Ong. (1995). The use of demographic studies in mangrove silviculture. Hydrobiologica, 295:255-26. http://dx.doi.org/10.1007/BF00029132

Japar, S. (1994). Mangrove plant resources in the Asean region. In Proceedings Third ASEAN- Australia Symposium on Living Coastal Resources, Vol. 1, Status Reviews, eds. C.R. Wilkinson, S.Sudara \& L.M Chou. Chulalongkorn University, Bangkok, Thailand.

Krebbs, C.J. (1998). Ecological Methodology. $2^{\text {nd }}$ edition. Addison-Wesley Educational Publishers, Inc. pp.410-454.

Latiff, A. (2004). Conservation of Mangrove Biodiversity in Peninsular Malaysia. National Conference on Sustainable Management of Matang Mangroves- 100 Years and Beyond. 5-8 October 2004, Ipoh, Perak, Malaysia.

Lokman, M.H. \& I. Sulong. (2001). Mangroves of Terengganu. Mangrove Research Unit (MARU) and Forestry Department Peninsular Malaysia. 135 pp.

Mitsch, W.J. \& J.G. Gosselink. (1993). Wetlands. $2^{\text {nd }}$ edn. Van Nostrand Reinhold, New York

Naskar, K.R. (2004). Manual of Indian Mangroves. Daya Publishing House, New Delhi, India.

Ng, F.S.P. (eds.). (1978). Tree Flora of Malaya. A manual for Foresters. Vol. 3. Longman Malaysia Sdn. Bhd.

Ng, F.S.P. (eds.). (1989). Tree Flora of Malaya. A Manual for Foresters. Vol. 4. Longman Malaysia Sdn. Bhd.

Ng, P.K.L. \& Sivasothi. N. (1999). A guide to the mangrove of Singapore 1. The Ecosystem and Plant Diversity. Singapore Science Centre, Singapore.

Norhayati, A. \& Latiff, A. (2001). Biomass and species composition of a mangrove forest in Pulau Langkawi, Malaysia. Mal. Appl. Biol., 30; 75-80. phytosociological characters. Ecology, 31: 435 - 455.

Odum WE, McIvor CC, Smith TJ III. (1982). The ecology of the mangroves of South Florida: a community profile. FWS/OBS-81/24. US Fish and Wildlife Service, Office of Biological Services, Washington, DC.

Rozainah M.Z. \& M.R Mohamad. (2006). Mangrove Tree Species Composition and Density in Balok River, Pahang, Malaysia. Ecoprint, 13: 23-28.

Tomlinson, P. B. (1986). The botany of mangroves. Cambridge University Press, New York. 413 pp.

Upadhyay, V.P., R. Ranjan \& J.S. Singh. (2002). Human-mangrove conflicts: The way out. Current Science, 83: 1328-1336.

Whitmore, T.C. (eds). (1973). Tree Flora of Malaya. A manual for Foresters. Vol. 2 Longman Malaysia Sdn. Bhd.

Whitmore, T.C. (eds.). (1972). Tree Flora of Malaya. A manual for Foresters. Vol. 1 Longman Malaysia Sdn. Bhd.

Woodroffe, C.D. (2002). Coasts: Form, Process and Evolution. Cambridge University Press, U.K.

\section{Notes}

Note 1. Table I and Table II are placed here

Note 2. Table III and Table IV are placed here

Note 3. Table V and Table VI are placed here

Note 4. Table VII is placed here 
Table 1. Summary of the floristic composition of Kilim, Geopark, Malaysia assessed from November 2009 until February 2010

\begin{tabular}{|c|c|c|c|c|}
\hline Area & Species & Genus & Family & No. of Stem \\
\hline \multirow[t]{19}{*}{ River Kilim } & 1. Avicennia officinalis & 1. Avicennia & 1. Avicenniaceae & 20 \\
\hline & 2. Bruguiera gymnorhiza & 2. Bruguiera & 2. Rhizophoraceae & 17 \\
\hline & 3. Bruguiera parviflora & & & 424 \\
\hline & 4. Bruguiera sexangula & & & 465 \\
\hline & 5. Ceriops tagal & 3. Ceriops & & 1264 \\
\hline & 6. Cycas siamensis & 4. Cycas & 3. Cycadaceae & 3 \\
\hline & 7. Memecylon edule Roxb. var. ovatum & 5. Memecylon & 4. Lythraceae & 1 \\
\hline & 8. Memecylon pauciflorum & & & 1 \\
\hline & 9. Murraya paniculata & 6. Murraya & 5. Rutaceae & 2 \\
\hline & 10. Pentaspadon curtisii & 7. Pentaspadon & 6. Anacardiaceae & 3 \\
\hline & 11. Rhizophora apiculata & 8. Rhizophora & 7. Rhizophoraceae & 1226 \\
\hline & 12. Rhizophora mucronata & & & 455 \\
\hline & 13. Streblus ilicifolius & 9. Streblus & 8. Moraceae & 19 \\
\hline & 14. Streblus laxiflorus & & 9. Moraceae & 1 \\
\hline & 15. Xanthophyllum discolor & 10. Xanthopyllum & 10. Polygalaceae & 8 \\
\hline & 16. Xylocarpus granatum & 11. Xylocarpus & 11. Meliaceae & 124 \\
\hline & 17. Xylocarpus moluccensis & & & 18 \\
\hline & Total & & & 4051 \\
\hline & 1. Avicennia marina & 1. Avicennia & 1. Avicenniaceae & 55 \\
\hline \multirow[t]{37}{*}{ River Kisap } & 2. Bruguiera cylindrica & 2. Bruguiera & 2. Rhizophoraceae & 1110 \\
\hline & 3. Bruguiera parviflora & & & 311 \\
\hline & 4. Ceriops decandra & 3. Ceriops & & 1 \\
\hline & 5. Ceriops tagal & & & 367 \\
\hline & 6. Cinnamomun sp. & 4. Cinnamomun & 3. Lauraceae & 4 \\
\hline & 7. Diospyros ismailii & 5. Diospyros & 4. Ebenaceae & 21 \\
\hline & 8. Elaeocarpus griffithii & 6. Elaeocarpus & 5. Elaeocarpaceae & 1 \\
\hline & 9. Erythroxylum cuneatum & 7. Erythroxylum & 6. Erythroxylaceae & 9 \\
\hline & 10. Excoecaria agallocha & 8. Excoecaria & 7. Euphorbiaceae & 4 \\
\hline & 11. Fagraea curtisii & 9. Fagraea & 8. Loganiaceae & 7 \\
\hline & 12. Fernando adenophylla & 10. Fernando & 9. Bignoniaceae & 10 \\
\hline & 13. Ficus deltoidea & 11. Ficus & 10. Moraceae & 5 \\
\hline & 14. Ficus rumpii & & & 2 \\
\hline & 15. Ficus superba & & & 4 \\
\hline & 16. Flacourtia rukam & 12. Flacourtia & 11. Flacourtiaceae & 3 \\
\hline & 17. Heritiera littoralis & 13. Heritiera & 12. Sterculiaceae & 4 \\
\hline & 18. Hydnocarpus ilicifolia & 14. Hydnocarpus & 13. Flacourtiaceae & 4 \\
\hline & 19. Lagerstroemia floribunda & 15. Lagerstroemia & 14. Lythraceae & 9 \\
\hline & 20. Macaranga sp. & 16. Macaranga & 15. Euphorbiaceae & 1 \\
\hline & 21. Mallotus brevipetiolatus & 17. Mallotus & & 4 \\
\hline & 22. Mallotus dispar & & & 2 \\
\hline & 23. Memecylon edule Roxb. var. ovatum & 18. Memecylon & 16. Lythraceae & 18 \\
\hline & 24. Memecylon pauciflorum & & & 35 \\
\hline & 25. Microcos sp. & 19. Microcos & 17. Tiliaceae & 1 \\
\hline & 26. Pentace sp. & 20. Pentace & & 3 \\
\hline & 27. Pentaspandon curtisii & 21. Pentaspadon & 18. Anacardiaceae & 9 \\
\hline & 28. Pentaspandon velutinis & & & 1 \\
\hline & 29. Phyllanthus pulcher & 22. Phyllanthus & 19. Euphorbiaceae & 15 \\
\hline & 30. Psychotria angulata & 23. Psychotria & 20. Rubiaceae & 1 \\
\hline & 31. Pterospermum lanceaefolium & 24. Pterospermum & 21. Sterculiaceae & 5 \\
\hline & 32. Radermachera pinnata & 25. Radermachera & 22. Bignoniaceae & 11 \\
\hline & 33. Radermachera stricta & & & 3 \\
\hline & 34. Rhizophora apiculata & 26. Rhizophora & 23. Rhizophoraceae & 1114 \\
\hline & 35. Rhizophora mucronata & & & 244 \\
\hline & 36. Schefflera heterophylla & 27. Schefflera & 24. Araliaceae & 2 \\
\hline & 37. Spatodea companulata & 28. Spatodea & 25. Bignoniaceae & 9 \\
\hline & 38. Spondias pinnata & 29. Spondias & 26. Anacardiaceae & 2 \\
\hline
\end{tabular}




\begin{tabular}{|c|c|c|c|c|}
\hline & 39. Sterculia augustifolia & 30. Sterculia & 27. Sterculiaceae & 17 \\
\hline & 40. Sterculia lancaviensis & & & 19 \\
\hline & 41. Streblus ilicifolius & 31. Streblus & 28. Moraceae & 41 \\
\hline & 42. Syzgium $\mathrm{sp}$. & 32. Syzgium & 29.Myrtaceae & 3 \\
\hline & 43. Terminallia triptera & 33. Terminallia & 30. Combretaceae & 5 \\
\hline & 44. Vitex pinnata & 34. Vitex & 31. Verbenaceae & 1 \\
\hline & 45. Xanthophyllum affine & 35. Xanthophyllum & 32. Polygalaceae & 3 \\
\hline & 46. Xanthophyllum discolor & & & 3 \\
\hline & 47. Xylocarpus granatum & 36. Xylocarpus & 33. Meliaceae & 253 \\
\hline & 48. Xylocarpus moluccensis & & & 76 \\
\hline & Total & & & 3832 \\
\hline & 1. Avicennia marina & 1. Avicennia & 1. Avicenniaceae & 37 \\
\hline \multirow{17}{*}{ River Ayer Hangat } & 2. Bruguiera cylindrica & 2. Bruguiera & 2. Rhizophoraceae & 62 \\
\hline & 3. Bruguiera parviflora & & & 91 \\
\hline & 4. Ceriops tagal & 3. Ceriops & & 429 \\
\hline & 5. Diospyros ferrea & 4. Diospyros & 3. Ebenaceae & 1 \\
\hline & 6. Excoecaria agallocha & 5. Excoecaria & 4. Euphorbiaceae & 1 \\
\hline & 7. Ficus superba & 6. Ficus & 5. Moraceae & 1 \\
\hline & 8. Pentaspadon motleyi & 7. Pentaspadon & 6. Anacardiaceae & 1 \\
\hline & 9. Rhizophora apiculata & 8. Rhizophora & 7. Rhizophoraceae & 1109 \\
\hline & 10. Rhizophora mucronata & & & 265 \\
\hline & 11. Sonneratia alba & 9. Sonneratia & 8. Lythraceae & 1 \\
\hline & 12. Streblus ilicifolius & 10. Streblus & 9. Moraceae & 5 \\
\hline & 13. Xanthophyllum affine & 11. Xanthophyllum & 10. Polygalaceae & 4 \\
\hline & 14. Xylocarpus granatum & 12. Xylocarpus & 11. Meliaceae & 1517 \\
\hline & 15. Xylocarpus moluccensis & & & 27 \\
\hline & 16. Xylocarpus rumphii & & & 54 \\
\hline & Total & & & 3605 \\
\hline & Grand Total & & & 11488 \\
\hline
\end{tabular}

Table 2. Floristic composition and dominance family of Kilim, Geoforest Park, Malaysia assessed from November 2009 until February 2010

\begin{tabular}{|l|c|c|c|r|}
\hline \multicolumn{1}{|c|}{ Family } & Genera & Species & No.of Stem & Percent (\%) \\
\hline Anacardiaceae & 2 & 4 & 16 & 0.14 \\
\hline Araliaceae & 1 & 1 & 2 & 0.02 \\
\hline Avicenniaceae & 1 & 2 & 112 & 0.97 \\
\hline Bignoniaceae & 3 & 4 & 33 & 0.29 \\
\hline Combretaceae & 1 & 1 & 5 & 0.04 \\
\hline Cycadaceae & 1 & 1 & 3 & 0.03 \\
\hline Ebenaceae & 1 & 2 & 22 & 0.19 \\
\hline Elaeocarpaceae & 1 & 1 & 1 & 0.01 \\
\hline Erythroxylaceae & 1 & 1 & 9 & 0.08 \\
\hline Euphorbiaceae & 4 & 5 & 27 & 0.24 \\
\hline Flacourtiaceae & 2 & 2 & 7 & 0.06 \\
\hline Lauraceae & 1 & 1 & 4 & 0.03 \\
\hline Loganiaceae & 1 & 1 & 7 & 0.06 \\
\hline Lythraceae & 3 & 4 & 65 & 0.57 \\
\hline Meliaceae & 1 & 3 & 2069 & 18.01 \\
\hline Moraceae & 1 & 5 & 78 & 0.68 \\
\hline Myrtaceae & 1 & 1 & 3 & 0.03 \\
\hline Polygalaceae & 1 & 2 & 18 & 0.16 \\
\hline Rhizophoraceae & 3 & 8 & 8954 & 77.94 \\
\hline Rubiaceae & 1 & 1 & 1 & 0.01 \\
\hline Rutaceae & 1 & 1 & 2 & 0.02 \\
\hline Sterculiaceae & 2 & 4 & 45 & 0.39 \\
\hline Tiliaceae & 2 & 2 & 4 & 0.03 \\
\hline Verbenaceae & 1 & 1 & 1 & 0.01 \\
\hline Total & $\mathbf{3 7}$ & $\mathbf{5 8}$ & $\mathbf{1 1 4 8 8}$ & \\
\hline
\end{tabular}


Table 3. List of true mangrove species together with their taxonomical rank of Kilim, Geoforest Park, Malaysia

\begin{tabular}{|c|c|c|c|c|}
\hline Area & Species & Genus & Family & No. of Stem \\
\hline \multirow{10}{*}{ River Kilim } & 1. Avicennia officinalis & 1. Avicennia & 1. Avicenniaceae & 20 \\
\hline & 2. Bruguiera gymnorhiza & 2. Bruguiera & 2. Rhizophoraceae & 17 \\
\hline & 3. Bruguiera parviflora & & & 424 \\
\hline & 4. Bruguiera sexangula & & & 465 \\
\hline & 5. Ceriops tagal & 3. Ceriops & & 1264 \\
\hline & 6. Rhizophora apiculata & & & 1226 \\
\hline & 7. Rhizophora mucronata & & & 455 \\
\hline & 8. Xylocarpus granatum & 4. Xylocarpus & 3. Meliaceae & 124 \\
\hline & 9. Xylocarpus moluccensis & & & 18 \\
\hline & Total & & & 4013 \\
\hline \multirow{12}{*}{ River Kisap } & 1. Avicennia marina & 1. Avicennia & 1. Avicenniaceae & 55 \\
\hline & 2. Bruguiera cylindrica & 2. Bruguiera & 2. Rhizophoraceae & 1110 \\
\hline & 3. Bruguiera parviflora & & & 311 \\
\hline & 4. Ceriops decandra & 3. Ceriops & & 1 \\
\hline & 5. Ceriops tagal & & & 367 \\
\hline & 6. Excoecaria agallocha & 4. Excoecaria & 3. Euphorbiaceae & 4 \\
\hline & 8. Heritiera littoralis & 5. Heritiera & 4. Sterculiaceae & 4 \\
\hline & 9. Rhizophora apiculata & 6. Rhizophora & 5. Rhizophoraceae & 1114 \\
\hline & 10. Rhizophora mucronata & & & 244 \\
\hline & 11. Xylocarpus granatum & 7. Xylocarpus & 6. Meliaceae & 253 \\
\hline & 12. Xylocarpus moluccensis & & & 76 \\
\hline & Total & & & 3539 \\
\hline \multirow{13}{*}{ River Ayer Hangat } & 1. Avicennia marina & 1. Avicennia & 1. Avicenniaceae & 37 \\
\hline & 2. Bruguiera cylindrica & 2. Bruguiera & 2. Rhizophoraceae & 62 \\
\hline & 3. Bruguiera parviflora & & & 91 \\
\hline & 4. Ceriops tagal & 3. Ceriops & & 429 \\
\hline & 5. Excoecaria agallocha & 4. Excoecaria & 3. Euphorbiaceae & 1 \\
\hline & 6. Rhizophora apiculata & 5. Rhizophora & 4. Rhizophoraceae & 1109 \\
\hline & 7. Rhizophora mucronata & & & 265 \\
\hline & 8. Sonneratia alba & 6. Sonneratia & 5. Lythraceae & 1 \\
\hline & 9. Xylocarpus granatum & 7. Xylocarpus & 6. Meliaceae & 1517 \\
\hline & 10. Xylocarpus moluccensis & & & 27 \\
\hline & 11. Xylocarpus rumphii & & & 54 \\
\hline & Total & & & 3593 \\
\hline & Grand Total & & & 11145 \\
\hline
\end{tabular}

Table 4. True mangrove species composition and dominance family of Kilim, Geoforest Park, Malaysia

\begin{tabular}{|l|c|c|c|c|}
\hline \multicolumn{1}{|c|}{ Family } & Genera & Species & No.of Stem & Percent (\%) \\
\hline 1. Rhizophoraceae & 3 & 8 & 8954 & 80.22 \\
\hline 2. Meliaceae & 1 & 3 & 2069 & 18.54 \\
\hline 3. Avicenniaceae & 1 & 2 & 112 & 1.00 \\
\hline 4. Euphorbiaceae & 4 & 5 & 27 & 0.24 \\
\hline \multicolumn{1}{|c|}{ Total } & 9 & 18 & 11162 & 100 \\
\hline
\end{tabular}


Table 5. Overall importance value index (IVI), density and frequency of true mangrove and associate species assessed in Kilim, Geoforest Park, Malaysia

\begin{tabular}{|c|c|c|c|c|}
\hline $\begin{array}{l}\text { Species } \\
\end{array}$ & Family & Density & Frequency & IVI \\
\hline Avicennia marina & Avicenniaceae & 92 & 48 & 7.80 \\
\hline Avicennia officinalis & Avicenniaceae & 20 & 12 & 2.87 \\
\hline Bruguiera cylindrica & Rhizophoraceae & 1171 & 82 & 22.60 \\
\hline Bruguiera gymnorhiza & Rhizophoraceae & 17 & 2 & 4.95 \\
\hline Bruguiera parviflora & Rhizophoraceae & 826 & 167 & 22.13 \\
\hline Bruguiera sexangula & Rhizophoraceae & 465 & 49 & 11.30 \\
\hline Ceriops decandra & Rhizophoraceae & 1 & 1 & 0.08 \\
\hline Ceriops tagal & Rhizophoraceae & 2060 & 228 & 45.85 \\
\hline Cinnamomun sp. & Lauraceae & 4 & 3 & 0.33 \\
\hline Cycas siamensis & Cycadaceae & 3 & 1 & 0.10 \\
\hline Diospyros ferrea & Ebenaceae & 1 & 1 & 0.09 \\
\hline Diospyros ismailii & Ebenaceae & 21 & 5 & 0.59 \\
\hline Elaeocarpus griffithii & Elaeocarpaceae & 1 & 1 & 0.08 \\
\hline Erythroxylum cuneatum & Erythroxylaceae & 9 & 6 & 0.61 \\
\hline Excocaria agollacha & Euphorbiaceae & 5 & 4 & 0.38 \\
\hline Fagraea curtisii & Loganiaceae & 7 & 1 & 0.14 \\
\hline Fernando adenophylla & Bignoniaceae & 10 & 5 & 0.76 \\
\hline Ficus deltoidea & Moraceae & 5 & 3 & 0.35 \\
\hline Ficus rumpii & Moraceae & 2 & 1 & 0.11 \\
\hline Ficus superba & Moraceae & 5 & 3 & 0.21 \\
\hline Ficus superba & Moraceae & 3 & 2 & 0.11 \\
\hline Flacourtia rukam & Flacourtiaceae & 4 & 3 & 0.18 \\
\hline Heritiera littoralis & Sterculiaceae & 4 & 1 & 0.43 \\
\hline Hydnocarpus ilicifolia & Flacourtiaceae & 9 & 5 & 0.12 \\
\hline Lagerstroemia floribunda & Lythraceae & 1 & 1 & 0.61 \\
\hline Macaranga sp. & Euphorbiaceae & 4 & 3 & 0.08 \\
\hline Mallotus brevipetiolatus & Euphorbiaceae & 2 & 2 & 0.28 \\
\hline Mallotus dispar & Euphorbiaceae & 1 & 6 & 0.08 \\
\hline Memecylon edule Roxb. var. ovatum & Lythraceae & 19 & 13 & 0.77 \\
\hline Memecylon pauciflorum & Lythraceae & 36 & 1 & 1.59 \\
\hline Microcos sp. & Tiliaceae & 2 & 2 & 0.09 \\
\hline Murraya paniculata & Rutaceae & 3 & 2 & 0.16 \\
\hline Pentace sp. & Tiliaceae & 1 & 1 & 0.19 \\
\hline Pentaspadon motleyi & Anacardiaceae & 12 & 5 & 0.09 \\
\hline Pentaspandon curtisii & Anacardiaceae & 1 & 1 & 0.79 \\
\hline Pentaspandon velutinis & Anacardiaceae & 15 & 7 & 0.09 \\
\hline Phyllanthus pulcher & Euphorbiaceae & 1 & 1 & 0.80 \\
\hline Psychotria angulata & Rubiaceae & 5 & 3 & 0.08 \\
\hline Pterospermum lanceaefolium & Sterculiaceae & 11 & 6 & 0.26 \\
\hline Radermachera pinnata & Bignoniaceae & 3 & 1 & 0.91 \\
\hline Radermachera stricta & Bignoniaceae & 14 & 326 & 0.19 \\
\hline Rhizophora apiculata & Rhizophoraceae & 3449 & 144 & 87.57 \\
\hline Rhizophora mucronata & Rhizophoraceae & 964 & 2 & 30.29 \\
\hline Schefflera heterophylla & Araliaceae & 1 & 1 & 0.18 \\
\hline Sonneratia alba & Lythraceae & 9 & 5 & 0.16 \\
\hline Spatodea companulata & Bignoniaceae & 11 & 1 & 0.66 \\
\hline Spondias pinnata & Anacardiaceae & 2 & 6 & 0.16 \\
\hline Sterculia lancaviensis & Sterculiaceae & 19 & 6 & 1.62 \\
\hline Streblus ilicifolius & Moraceae & 65 & 15 & 1.84 \\
\hline Streblus laxiflorus & Moraceae & 1 & 1 & 0.08 \\
\hline Syzgium sp. & Myrtaceae & 3 & 2 & 0.21 \\
\hline Terminallia triptera & Combretaceae & 5 & 3 & 0.29 \\
\hline Vitex pinnata & Verbenaceae & 1 & 1 & 0.10 \\
\hline Xanthophyllum discolor & Polygalaceae & 11 & 5 & 0.49 \\
\hline Xantophyllum affine & Polygalaceae & 7 & 3 & 0.30 \\
\hline Xylocarpus granatum & Meliaceae & 1894 & 171 & 40.47 \\
\hline Xylocarpus moluccensis & Meliaceae & 121 & 35 & 5.18 \\
\hline Xylocarpus rumphii & Meliaceae & 54 & 6 & 1.19 \\
\hline Total & & 11488 & 1422 & 300.00 \\
\hline
\end{tabular}


Table 6. Importance value index (IVI) of true mangrove and associate species assessed in River Kilim, River Kisap and River Ayer Hangat of Kilim, Geoforest Park, Malaysia

\begin{tabular}{|c|c|c|c|}
\hline Species & River Kilim & River Kisap & River Ayer Hangat \\
\hline Avicennia marina & nd & 10.39 & 14.3 \\
\hline Avicennia officinalis & 7.99 & nd & nd \\
\hline Bruguiera cylindrica & nd & 58.21 & 7.72 \\
\hline Bruguiera gymnorhiza & 13.32 & nd & nd \\
\hline Bruguiera parviflora & 28.48 & 23.29 & 14.24 \\
\hline Bruguiera sexangula & 32.07 & nd & nd \\
\hline Ceriops decandra & nd & 0.22 & nd \\
\hline Ceriops tagal & 70.42 & 24.37 & 42.2 \\
\hline Cinnamomun sp. & nd & 0.91 & nd \\
\hline Cycas siamensis & 0.29 & nd & nd \\
\hline Diospyros ferrea & nd & nd & 0.3 \\
\hline Diospyros ismailii & nd & 1.63 & nd \\
\hline Elaeocarpus griffithii & nd & 0.22 & nd \\
\hline Erythroxylum cuneatum & nd & 1.66 & nd \\
\hline Excocaria agollacha & nd & 0.82 & 0.27 \\
\hline Fagraea curtisii & nd & 0.38 & nd \\
\hline Fernando adenophylla & nd & 2.37 & nd \\
\hline Ficus deltoidea & nd & 0.97 & 0.38 \\
\hline Ficus rumpii & nd & 0.29 & nd \\
\hline Ficus superba & nd & 0.58 & nd \\
\hline Flacourtia rukam & nd & 0.49 & nd \\
\hline Heritiera littoralis & nd & 1.19 & nd \\
\hline Hydnocarpus ilicifolia & nd & 0.35 & nd \\
\hline Lagerstroemia floribunda & nd & 1.68 & nd \\
\hline Macaranga sp. & nd & 0.22 & nd \\
\hline Mallotus brevipetiolatus & nd & 0.75 & nd \\
\hline Mallotus dispar & nd & 0.44 & nd \\
\hline Memecylon edule Roxb. var. ovatum & 0.26 & 1.88 & nd \\
\hline Memecylon pauciflorum & 0.25 & 4.16 & nd \\
\hline Microcos sp. & nd & 0.24 & nd \\
\hline Murraya paniculata & 0.48 & nd & nd \\
\hline Pentace sp. & nd & 0.52 & nd \\
\hline Pentaspadon motleyi & nd & nd & 0.31 \\
\hline Pentaspandon curtisii & 0.29 & 1.91 & nd \\
\hline Pentaspandon velutinis & nd & 0.24 & nd \\
\hline Phyllanthus pulcher & nd & 2.20 & nd \\
\hline Psychotria angulata & nd & 0.22 & nd \\
\hline Pterospermum lanceaefolium & nd & 0.72 & nd \\
\hline Radermachera pinnata & nd & 0.54 & nd \\
\hline Radermachera stricta & nd & 2.52 & nd \\
\hline Rhizophora apiculata & 89.84 & 79.04 & 95.31 \\
\hline Rhizophora mucronata & 36.9 & 26.45 & 27.06 \\
\hline Schefflera heterophylla & nd & 0.49 & nd \\
\hline Sonneratia alba & nd & nd & 0.55 \\
\hline Spatodea companulata & nd & 1.57 & nd \\
\hline Spondias pinnata & nd & 0.44 & nd \\
\hline Sterculia augustifolia & nd & 2.24 & nd \\
\hline Sterculia lancaviensis & nd & 2.24 & nd \\
\hline Streblus ilicifolius & 1.27 & 3.37 & 0.67 \\
\hline Streblus laxiflorus & 0.24 & nd & nd \\
\hline Syzgium sp. & nd & 0.57 & nd \\
\hline Terminallia triptera & nd & 0.78 & nd \\
\hline Vitex pinnata & nd & 0.27 & nd \\
\hline Xanthophyllum discolor & 0.87 & 0.56 & nd \\
\hline Xanthophyllum affine & nd & 0.49 & 0.4 \\
\hline Xylocarpus granatum & 12.86 & 0.56 & 89.53 \\
\hline Xylocarpus moluccensis & 4.17 & 26.76 & 2.73 \\
\hline Xylocarpus rumphii & nd & 8.14 & 4.03 \\
\hline Total & 300 & 300 & 300 \\
\hline
\end{tabular}

Note: nd $=$ not detected 
Table 7. Overall family value index (FVI), density, frequency and basal area of true mangrove and associate species assessed in Kilim Geoforest Park, Malaysia.

\begin{tabular}{|l|c|c|c|c|}
\hline \multicolumn{1}{|c|}{ Family } & Density & Frequency & Basal Area & FVI \\
\hline Anacardiaceae & 16 & 8 & 0.279 & 1.13 \\
\hline Araliaceae & 2 & 2 & 0.014 & 0.18 \\
\hline Avicenniaceae & 112 & 60 & 3.591 & 10.66 \\
\hline Bignoniaceae & 33 & 17 & 0.693 & 2.53 \\
\hline Combretaceae & 5 & 3 & 0.021 & 0.29 \\
\hline Cycadaceae & 3 & 1 & 0.002 & 0.10 \\
\hline Ebenaceae & 22 & 6 & 0.039 & 0.67 \\
\hline Elaeocarpaceae & 1 & 1 & 0.002 & 0.08 \\
\hline Erythroxylaceae & 9 & 6 & 0.069 & 0.61 \\
\hline Euphorbiaceae & 27 & 17 & 0.177 & 1.62 \\
\hline Flacourtiaceae & 7 & 3 & 0.022 & 0.31 \\
\hline Lauraceae & 4 & 3 & 0.057 & 0.33 \\
\hline Loganiaceae & 7 & 1 & 0.003 & 0.14 \\
\hline Lythraceae & 65 & 25 & 0.521 & 3.12 \\
\hline Meliaceae & 2069 & 212 & 9.130 & 46.84 \\
\hline Moraceae & 78 & 23 & 0.268 & 2.70 \\
\hline Myrtaceae & 3 & 2 & 0.027 & 0.21 \\
\hline Polygalaceae & 18 & 8 & 0.048 & 0.79 \\
\hline Rhizophoraceae & 8954 & 999 & 50.270 & 224.77 \\
\hline Rubiaceae & 1 & 1 & 0.001 & 0.08 \\
\hline Rutaceae & 2 & 2 & 0.001 & 0.16 \\
\hline Sterculiaceae & 45 & 18 & 0.430 & 2.31 \\
\hline Tiliaceae & 4 & 3 & 0.021 & 0.28 \\
\hline Verbenaceae & 1 & 1 & 0.013 & 0.10 \\
\hline Total & 11488 & 1422 & 65.699 & 300.00 \\
\hline & & & & \\
\hline & & 17 & 17 \\
\hline
\end{tabular}

Table 8. Species diversity of mangrove forest were assessed in three areas at Kilim, Geoforest Park, Malaysia from November 2010 until February 2011.

a) Species Richness

\begin{tabular}{|l|c|c|c|}
\hline \multicolumn{1}{|c|}{ Diversity indices } & River Kilim & River Kisap & River Ayer Hangat \\
\hline Jackknife estimates of species richness & 24.7 & 62.6 & 25.7 \\
Number of unique species & 8 & 15 & 8 \\
\hline
\end{tabular}

b) Species Heterogeneity

\begin{tabular}{|l|c|c|c|}
\hline Diversity indices & River Kilim & River Kisap & River Ayer Hangat \\
\hline Simpson's index of diversity (1-D) & 0.773 & 0.806 & 0.695 \\
Shannon-Wiener index of diversity H' & 2.44 & 3.004 & 2.084 \\
Brillouin index of diversity & 2.427 & 2.971 & 2.072 \\
\hline
\end{tabular}

c) Species Evenness

\begin{tabular}{|l|c|c|c|}
\hline Diversity indices & River Kilim & River Kisap & River Ayer Hangat \\
\hline Simpson's measure of evenness & 0.259 & 0.108 & 0.205 \\
Camargo's index of evenness & 0.251 & 0.139 & 0.201 \\
Smith and Wilson's Index of Evenness & 0.101 & 0.178 & 0.092 \\
\hline
\end{tabular}

